\title{
Determinants of Knowledge and Behaviours of Indonesian Health Care Providers toward the Prevention of COVID-19
}

\author{
Yoyok Bekti Prasetyo ${ }^{1 *} \oplus$, Alhisna Fitri Setyamardina ${ }^{2} \oplus$, Henik Tri \\ Rahayu $^{3} \odot$, Titih Huriah ${ }^{4} \odot$ \\ 1Department of Community Health Nursing, Faculty of Health Sciences, Universitas \\ Muhammadiyah of Malang, Malang, Indonesia \\ ${ }^{2}$ Bachelor of Nursing Student, Faculty of Health Sciences, Universitas Muhammadiyah \\ of Malang, Malang, Indonesia \\ ${ }^{3}$ Department of Medical-Surgical Nursing, Faculty of Health Sciences, Universitas \\ Muhammadiyah of Malang, Malang, Indonesia \\ ${ }^{4}$ Department of Community Health Nursing, University Muhammadiyah of Yogyakarta, \\ Yogyakarta, Indonesia
}

\section{G open Access}

\section{Jurnal Keperawatan Padjadjaran (JKP)}

Volume $9(3), 167-174$ (C) The Author(s) 2021 http://dx.doi.org/ 10.24198/jkp. v9i3.1709

\section{Article Info}

Received : September 14, 2021 Revised : October 19, 2021

Accepted : October 20, 2021

Published : December 08, 2021

Corresponding author

Yoyok Bekti Prasetyo

Community Nursing Department,

Fakultas IImu Kesehatan, Uni-

versitas Muhammadiyah Malang,

Jl. Bendungan Sutami No 188A,

Sumbersari, Lowokwaru, Malang

East of Java, Indonesia, 65145;

Phone: +628125208825, E-mail:

yoyok@umm.ac.id

\section{Citation}

Prasetyo, Y.B., \& Setyamardina, A.F. (2021). Determinants of Knowledge and Behaviours of Indonesian Health Care Providers toward the Prevention of Covid-19. Jurnal Keperawatan Padjadjaran, 9(3), 167-174. http://dx.doi.org/ 10.24198/jkp.v9i3.1709

\section{Website}

http://jkp.fkep.unpad.ac.id/index. $\mathrm{php} / \mathrm{jkp}$

This is an Open Access article distributed under the terms of the Creative Commons Attribution-NonCommercial 4.0 International License.

\section{Abstract}

Background: Due to the high risk of exposure of Health Care Providers (HCPs) at the forefront of the COVID-19 responses, HCPs' knowledge and prevention behaviors towards COVID-19 have become crucial parts of their job performances.

Purpose: This study aims to identify the level of knowledge and prevention behaviors of HCPs toward COVID-19 and factors associates.

Methods: This study utilized a cross-sectional research design. The samples consisted of 182 HCPs in Malang, East Java Province, Indonesia. The data were collected through structured self-developed online questionnaires, consisting of socio-demographic characteristics, knowledge, and prevention behaviors. The data were treated as categorical data types and then analyzed using frequency distribution, chi-squares, and logistic regression performed by SPSS 22 software.

Results: The HCPs working at hospitals have about one time better knowledge than those who work at public health centers, clinics, and pharmacies (COR $=1.03 ; 95 \% \mathrm{Cl}: 0.72-14.76)$. Nurses have 3.4 times better knowledge than other HCPs (COR $=3.43 ; 95 \% \mathrm{Cl}$ : $0.27-43.84)$. HCPs with 5 to 10-year experience have 6.4 times better prevention behavior than those with less than five years or over 10 -year experience $(\mathrm{COR}=6.42 ; 95 \% \mathrm{Cl}$ : 0.57-72.76).

Conclusion: The knowledge and prevention behaviors of HCPs toward COVID-19 prevention were influenced by age, residence area, occupation, and the length of working experience. Therefore, HCPs need to understand the new healthy habits and actively contribute to COVID-19 intervention programs.

Keywords: health care providers; knowledge and behavior; COVID-19 prevention.

\section{Introduction}

TIn December 2019, pneumonia of unknown origin occurred in Wuhan City, Hubei Province, China, and became an outbreak. The genome was identified as a new type of coronavirus related to SARS-CoV, so it was named Severe Acute Respiratory Syndrome Coronavirus Type 2 (SARS-CoV-2), in which SARS-CoV-2 is a $\beta$-coronavirus belonging to the subgenus Sarbecovirus (Nuccetelli et al., 2020). The World Health Organization (WHO) considers that the virus was categorized as high risk at the global level and then stated a Public Health Emergency of International Concern (PHEIC) on January 30, 2020; and the global spread of SARS-CoV-2 and thousands of deaths from the COVID-19 caused the WHO to declare a pandemic on March 12, 2020 
(Nuccetelli et al., 2020).

By January 22, 2021, over 96 million had been confirmed COVID-19 positive and COVID-19 across 224 countries caused around 2.1 million deaths (WHO, 2020). In Indonesia only, the number of confirmed cases of COVID-19 exceeded 2.1 million, and about 27.453 deaths were caused by it (Ministry of Health Republic of Indonesia, 2020). The mortality rate caused by COVID-19 reached $3.5 \%$, with the highest prevalence of deaths over 65 years old. Furthermore, there were 49,174 confirmed cases of COVID-19 in East Java, Indonesia, with the 1937 cases were reported from Malang City. The increasing number of confirmed cases occurred in Malang was mainly without symptoms and it reached 30,418 cases (Ministry of Health Republic of Indonesia, 2020).

Health care providers (HCPs) are at the forefront of the battle against COVID-19 (Saqlain et al., 2020). It is paramount that they have and practice adequate knowledge and behavior to prevent the widespread virus (Moudy \& Syakurah, 2020). Being at the forefront of the battle means HCPs have a higher risk of exposure to COVID-19 due to close contact with infected patients when facilitating the transmission process (Asemahagn, 2020; Cooper et al., 2020). COVID-19 has caused various occupational health problems with high severity on HCPs, including mortality. Besides, HCPs have endured psychological stress, extensive working hours, burnout, job stigma, and physical violence due to COVID-19 impacts, which leads to the reduction of HCPs' immunity and increase the risks of severe impacts of the disease (Fang et al., 2020; Rahman et al., 2020). The increasing mortality rate among HCPs is alarming, particularly during the COVID-19 and other infectious disease responses (Saqlain et al., 2020).

Inadequate knowledge and inappropriate attitude of health care providers can directly affect their behaviors and lead to delays in diagnosis, poor infection control, and the spread of diseases (Abdel Wahed et al., 2020). Health care providers' lack of compliance toward health protocols, such as going to a crowded place for shopping after work or violating social distancing, can expose HCPs to COVID-19 or even spread it (Tsegaye et al., 2021). Thus, it is crucial to promote health care providers' knowledge and prevention behavior of COVID-19 (Alimansur \& Quyumi, 2020). By improving their knowledge and skills, health care providers can provide better treatment to patients and become good role models to prevent COVID-19 spread (Olum et al., 2020). In the principal, the control and prevention of COVID-19 are crucial for three reasons: to prevent the virus transmission from patients to health care providers and vice versa, to prevent the spread of the virus, and to reduce the wastage of financial resources (Jemal et al., 2019).

In Indonesia, the study related to the issues mentioned earlier is still limited. Jemal et al. (2019) suggest that $89 \%$ of the HCPs involved in their study demonstrate adequate knowledge regarding COVID-19, and over $85 \%$ of them express their fear of getting infected by the virus. Olum et al. (2020) also suggest that about $54 \%$ of health care providers indicate a lack of knowledge on COVID-19 prevention. Some factors influencing the HCPs' knowledge and behaviors towards COVID-19 prevention include working experience and job category (Zhang et al., 2020). Thus, the current study aims to identify the level of knowledge and prevention behavior of health care providers toward COVID-19 and its associated factors.

\section{Methods}

\section{Study design and settings}

This study used a cross-sectional research design. The research was conducted between March to April 2021.

\section{Sample size determination and sampling procedures}

The population of this study was health care providers who work in hospitals and other health care facilities (public health centers, clinics, and private practices) in Malang, East Java Province of Indonesia. In 2019, the number of health workers in Malang included doctors (1263), nurses (3028), midwives (733), pharmacists (429), and others (1006). In total, 6459 health workers with different professional disciplines worked in various healthcare facilities (The Central Bureau of Statistics Malang, 2020). The sample size was calculated using G*Power 3.1 software with a medium effect size (0.15), a significance level of 0.05 , and power of study 0.80; required an estimated sample of 182 . The subjects who met inclusion criteria and willing to participate in this study were recruited. The online survey was distributed through messaging social media (WhatsApp); thus, the accidental sampling technique was applied.

\section{Data collection instruments and techniques} The data collected through online structured questionnaires consisted of self-developed sociodemographic characteristics, knowledge, and prevention behaviors towards COVID-19. The sociodemographic characteristics consisted of age (less than 30 and over 30 years), gender (males, females), region (rural and urban), workplace (hospitals, public health centers, clinics, pharmacies), occupations (doctors, nurses, others), work unit (COVID, nonCOVID), and the length of work experience (less than 5, 5-10, over ten years). The knowledge about COVID-19 was measured using self-developed questionnaires consisting of eight questions related to COVID-19, spread, and preventions (for instance: I understand that COVID-19 can infect humans and animals, People suspected of COVID-19 infection must isolate themselves for 14 days, undergoing 
Original Article

Determinants of Knowledge and Behaviours

Table 1. Respondent's Characteristics

\begin{tabular}{|c|c|c|}
\hline Characteristics & $\mathbf{n}$ & $\%$ \\
\hline \multicolumn{3}{|l|}{ Age } \\
\hline$<30$ years & 161 & 88.5 \\
\hline$>30$ years & 21 & 11.5 \\
\hline \multicolumn{3}{|l|}{ Gender } \\
\hline Males & 37 & 20.3 \\
\hline Females & 145 & 79.7 \\
\hline \multicolumn{3}{|l|}{ Residence } \\
\hline Rural & 83 & 45.6 \\
\hline Urban & 99 & 54.4 \\
\hline \multicolumn{3}{|l|}{ Workplace } \\
\hline Hospitals & 129 & 70.9 \\
\hline Public Health Centres & 27 & 14.8 \\
\hline Clinics & 23 & 12.6 \\
\hline Pharmacies & 3 & 1.6 \\
\hline \multicolumn{3}{|l|}{ Occupation } \\
\hline Nurses & 149 & 81.9 \\
\hline Doctors & 9 & 4.9 \\
\hline Others & 24 & 13.2 \\
\hline \multicolumn{3}{|l|}{ Work Unit } \\
\hline Incovid & 64 & 35.2 \\
\hline Noncovid & 118 & 64.8 \\
\hline \multicolumn{3}{|l|}{ Work Experience } \\
\hline$<5$ years & 118 & 64.8 \\
\hline $5-10$ years & 26 & 14.3 \\
\hline$>5$ years & 38 & 20.9 \\
\hline
\end{tabular}

Table 2. The determinants of health workers' knowledge and behavior

\begin{tabular}{|c|c|c|}
\hline \multirow[t]{2}{*}{ Variables } & Knowledge & Behavior \\
\hline & COR $(95 \% \mathrm{Cl})$ & COR $(95 \% \mathrm{Cl})$ \\
\hline \multicolumn{3}{|l|}{ Age } \\
\hline$<30$ years & $1.58(0.492-5.052)^{*}$ & $0.25(0.48-1.255)$ \\
\hline$>30$ years & Ref & Ref \\
\hline \multicolumn{3}{|l|}{ Gender } \\
\hline Males & $1.17(0.476-2.909)$ & $0.80(0.152-4.236)$ \\
\hline Females & Ref & Ref \\
\hline \multicolumn{3}{|l|}{ Residential area } \\
\hline Rural & $1.32(0.647-2.705)$ & $1.72(0.495-5.982)$ \\
\hline Urban & Ref & Ref \\
\hline \multicolumn{3}{|l|}{ Workplace } \\
\hline Hospitals & $1.03(0.72-14.76)$ & $0.15(0.007-2.987)$ \\
\hline Public Health Centres & $0.31(0.019-4.95)$ & $0.36(0.015-8.322)$ \\
\hline Clinics & $0.62(0.039-10.005)$ & $0.12(0.003-4.184)$ \\
\hline Pharmacies & Ref & Ref \\
\hline \multicolumn{3}{|l|}{ Occupations } \\
\hline Nurses & $3.43(0.269-4.384)^{*}$ & $0.60(0.109-3.350)$ \\
\hline Doctors & $0.73(0.236-2.277)^{*}$ & $0.82(0.050-13.45)$ \\
\hline Others & $\operatorname{Ref}$ & Ref \\
\hline
\end{tabular}


Cont. Table 2. The determinants of health workers' knowledge and behavior

\begin{tabular}{|c|c|c|}
\hline \multirow[t]{2}{*}{ Variables } & Knowledge & Behavior \\
\hline & COR $(95 \% \mathrm{CI})$ & COR $(95 \% \mathrm{CI})$ \\
\hline \multicolumn{3}{|l|}{ Work units } \\
\hline Incovid & $1.25(0.558-2.820)$ & $1.416(0.318-6.12)$ \\
\hline Noncovid & Ref & Ref \\
\hline \multicolumn{3}{|l|}{ Work experience } \\
\hline$<5$ years & $0.914(0.351-2.376)$ & $3.913(0.399-38.37)$ \\
\hline $5-10$ years & $0.953(0.286-3.176)$ & $6.419(0.566-72.76)$ \\
\hline$>5$ years & Ref & Ref \\
\hline
\end{tabular}

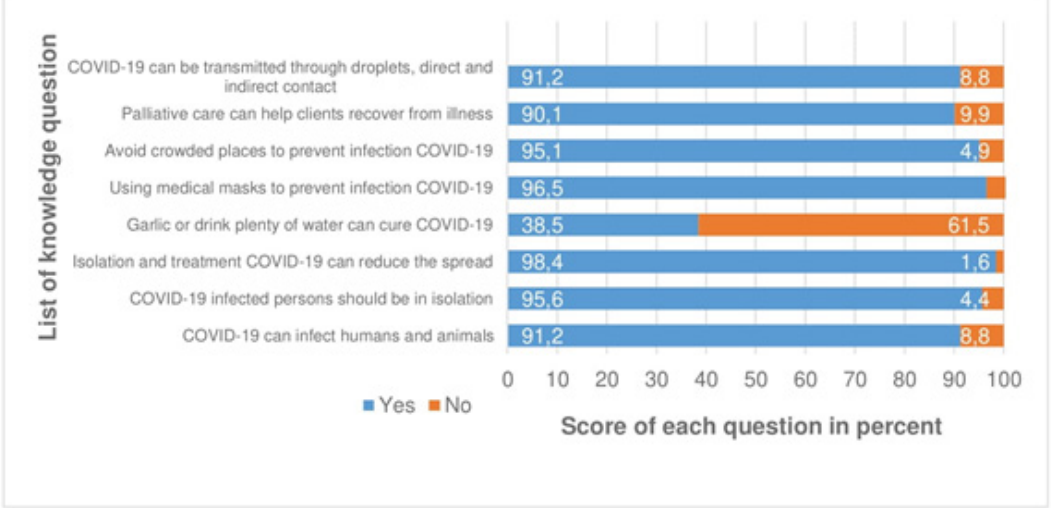

Figure 1. Knowledge of Health Workers about COVID-19 in The Malang Region of Indonesia, 2021

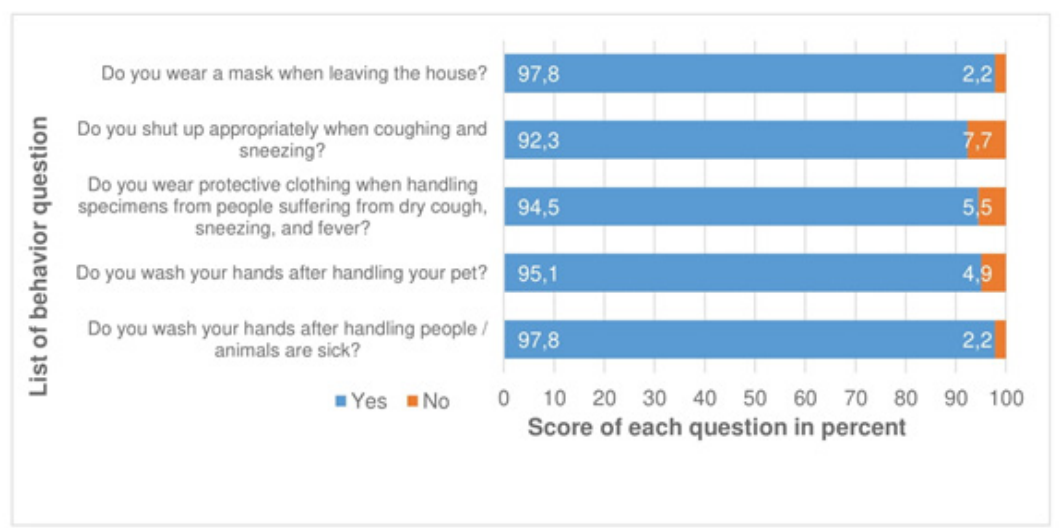

Figure 2. Behavior of Health Workers about COVID-19 in The Malang Region of Indonesia, 2021

isolation and receiving treatment when confirmed to be positive of COVID-19 will help reduce the spread of the virus). The prevention behavior was measured by using self-developed questionnaires consisting of five questions related to preventing COVID-19 (for instance: Do you wash your hands after taking care of patients? Do you wash your hands after interacting with pet animals? Do you wear protective gear while working? Do you cover your mouth when coughing and sneezing? Do you wear masks when you go out of your house?). This questionnaire was adopted and adapted to the conditions in Indonesia from research conducted by Asemahagn, M. A. in 2020 (Asemahagn, 2020) . Both knowledge and behaviors were answered with yes (1) or no (0), and data were categorized into two categories (good and poor). The questionnaires were designed using a Google Form (https://forms. gle/daT3Mo3ZZN3QYZ6v5), then distributed through the WhatsApp messaging application, then were downloaded into Microsoft-Excel format for further analysis.

\section{Data quality assurance}

The questionnaire was designed in a structure that was easy to follow. Its validity had been tested on medical experts, nurses, and pharmacists in the Faculty of Health Sciences of Muhammadiyah University of Malang, the Cronbach alpha coefficients were acceptable (0.65 for knowledge 
and 0.71 for prevention behaviors).

\section{Data Analyses}

The data were analyzed using a descriptive statistic (distribution of frequency and percentage), multinomial logistic regression analysis to identify the factors related to knowledge and prevention behavior of COVID-19. The relationship between the independent and dependent variables was described using a crude odds ratio (COR) with 95\% $\mathrm{Cl}$ and a p-value $<0.05$ to demonstrate the odds of each group without counting other variables. COR is used to measure the association between an exposure (age, gender, residence, work place, occupation, work unit and work experiences) and an outcome (knowledge and behaviors).

\section{Ethical approval}

The research ethics committee of the Faculty of Medicine, Universitas Muhammadiyah Malang (No.E.5.a/049/KEPK-UMM/IV/2021) gave this research their clearance. All of the participants signed a written informed consent form. Confidentiality and privacy were assured.

\section{Results}

\section{Respondent's Characteristics}

Out of 182 subjects, the majority of health care providers were less than 30 years old $(88.5 \%)$, worked at hospitals $(70.9 \%)$, responsible in COVID-19 treatment rooms $(35.2 \%)$, had less than five years of work experience $(64.8 \%)$, and were nurses $(81.9 \%)$ (Table 1).

\section{Knowledge and Prevention Behaviours of COVID-19}

Health care providers' knowledge regarding COVID-19 prevention was considered good, which seven items indicate a high percentage of HCPs correctly answered (above 90\%). Only item 5 (knowledge about the consumption of garlic and water to prevent COVID-19) was low (38.5\%). Despite a low percentage $(<10 \%)$, some HCPs demonstrated poor knowledge of the prevention of COVID-19 transmission (8.8\%) (Fig. 1). The prevention behaviors among HCPs were considered good (all items' percentages were above 90\%) (Fig. 2). However, some HCPs still need to pay more attention to their habits of covering their mouths when sneezing and coughing $(7.7 \%)$ and wear protective cloth when handling specimens of patients suffering from cough $(5.5 \%)$.

\section{The determinants of health care providers' knowledge and behavior}

Table 2 shows the influence of the determinant factors: age, gender, residence, workplace, occupation, work unit, and work experiences on the knowledge and prevention behaviors of COVID-19 among Indonesian HCPs. Young HCPs had 1.6 times better knowledge than older ones (COR = 1.58; 95\% Cl: 0.92-5.052). The HCPs who lived in rural areas had 1.7 times better behavior than those in urban areas (COR $=1.72 ; 95 \% \mathrm{Cl}$ : 0.495-5.982). HCPs who worked in hospitals had one time better knowledge than those who worked at public health centers, clinics, and pharmacies (COR $=1.03 ; 95 \%$ $\mathrm{Cl}$ : 0.72-14.76), where nurses had 3.4 times better knowledge than other HCPs (COR $=3.43 ; 95 \% \mathrm{Cl}$ : $0.269-43.84)$. Then, HCPs who had 5 to 10 years of work experience showed 6.4 times better prevention behaviors than those with less than five years or over ten years of work experience $(\mathrm{COR}=6.42$; 95\% Cl: 0.566-72.76).

\section{Discussion}

The study findings illustrated that most healthcare providers at the frontline of COVID-19 responses are young ( $<30$ years). This situation may result from the explosion of COVID-19 confirmed cases that forced many hospitals to massively recruited new HCPs to fulfill the demand for healthcare services. Most of the recruits were fresh graduates (Fang et al., 2020; Wright et al., 2020). This fact affects the level of knowledge and prevention behaviors of COVID-19 demonstrated by HCPs as age influences their perception and mindset (Sugawara \& Nikaido, 2014). Also, the study findings highlighted that the HCPs generally demonstrated good knowledge and prevention behaviors of COVID-19, which is in line with a study conducted by Yanti et al. (2020), which suggests that $99 \%$ of Indonesian citizens had had good knowledge and behaviors of the COVID-19 prevention programs. Health care providers' knowledge is crucial in the pandemics period, including the current situation of the COVID-19 outbreak (Asemahagn, 2020; Qian et al., 2020; Viswanathan et al., 2020), in which the HCPs' high level of knowledge significantly influences the number of cases and the prevention of COVID-19 (Haque et al., 2021; Shen et al., 2021). The proper prevention behaviors among HCPs might be achieved through the experiences, particularly during the battle against the COVID-19 pandemic. Besides, nurses have good knowledge because of their continuing education and experiences (AbouAbbas et al., 2020; Asemahagn, 2020; Tsegaye et al., 2021).

Younger HCPs show better knowledge than older colleagues; it is highlighted that the young can learn faster due to their adeptness in utilizing technology to access information (Abou-Abbas et al., 2020; Maude et al., 2021). Surprisingly, the HCPs who lived in rural areas demonstrated 1.7 times better prevention behaviors than those in urban areas; it was interesting where $\mathrm{HCPs}$ in cities should have better knowledge and prevention behaviors than others in rural areas. HCPs in rurals usually had limited internet connection and information due to limited facilities and being far away from the centers. 
It leads the HCPs who live in rural areas to have more efforts to upgrade their knowledge and apply behaviors independently as they can be a role model of their behaviors to society. Ashcroft et al. (2021) also mentioned a similar situation where health care providers in rural areas had faced various obstacles, including the limited internet network. Regarding the difficulty in accessing information, this study findings illustrated that it was mainly more challenging to encourage people who live in rural areas to comply with the health protocols such as wearing masks, maintaining physical distancing, as well as maintaining personal health compared to those who live in urban areas due to the differences educational and economic backgrounds (Singh et al., 2021). In other words, rural communities had low awareness of COVID-19 infection (Yue et al., 2021).

Further findings suggest that HCPs who worked in hospitals indicated better knowledge of COVID-19 prevention than other settings as hospitals were the referral healthcare to treating COVID-19 patients due to their adequate facilities. Besides, the COVID-19 cases in hospitals were usually much higher in number and complexities, so HCPs demanded to improve their knowledge and skills to provide better healthcare services (Qian et al., 2020; Saqlain et al., 2020; Zhang et al., 2020). Then, the findings also indicated that nurses had 3.4 times better knowledge than other HCPs because nurses took up the majority of responsibilities in healthcare facilities and spent the most hours providing healthcare services to patients. Accordingly, nurses were highly exposed to COVID-19 infection (Cai et al., 2020; Yifan et al., 2020); thus, continuous education and training on the newest updates of COVID-19 were being delivered to nurses and other health workers, as Maude et al. (Maude et al., 2021) claimed that the knowledge about the routes of transmission, general symptoms, and preventions was highly recommended to health workers (>80\%).

Lastly, the length of work experience influenced HCPs' knowledge which those who have 5-10 years of experience indicated to have 6.4 times better knowledge than those who have less or more. It highlights that more extended work experience exposes HCPs to more information and skills to provide better healthcare service to patients. Despite not being significant in this study, the evidence suggests that HCPs with over ten years of experience show three times better skills than those who work for a shorter period (Abou-Abbas et al., 2020). Thus, it can be concluded that experience and other demographic factors significantly influenced health care providers' knowledge and behaviors (Tamang et al., 2020).

\section{Conclusion}

This study concludes that most health workers in Malang, East Java Province of Indonesia, have adequate knowledge and behavior toward COVID-19 prevention. The findings suggest that health care providers' knowledge and behavior are mainly influenced by age, residential area, workplace, occupation, and work experience. This study would emphasize the importance of understanding and implementing the new healthy habits to contribute to the COVID-19 prevention program actively. Aside from that, HCPs need to periodically cool down and reinvigorate themselves, reduce their workload, go for spiritual retreats, and educate themselves on the COVID-19 updates.

\section{Limitations of the study}

This study utilized an online survey that had some limitations, such as that it only reached a certain number of respondents in Malang of East Java Province. Since the instrument mainly used internet connection, technology, and electricity, some potential respondents with limitations might not participate in the study, although they might have a significant contribution. Then, the instruments in this study were developed and validated using a simple process; other advanced validations processes might be needed to gain more rigorous findings.

\section{Acknowledgments}

The author would like to thank the Dean of the Faculty of Health Sciences, the University of Muhammadiyah Malang, who has provided support in completing this study.

\section{References}

Abdel Wahed, W. Y., Hefzy, E. M., Ahmed, M. I., \& Hamed, N. S. (2020). Assessment of knowledge, attitudes, and perception of health care workers regarding COVID-19, A cross-sectional study from Egypt. Journal of Community Health, 45(6), 1242-1251. https:// doi.org/10.1007/s10900-020-00882-0

Abou-Abbas, L., Nasser, Z., Fares, Y., Chahrour, M., El Haidari, R., \& Atoui, R. (2020). Knowledge and practice of physicians during COVID-19 pandemic: A cross-sectional study in Lebanon. BMC Public Health, 20(1), 1-9. https://doi. org/10.1186/s12889-020-09585-6

Alimansur, M., \& Quyumi, E. (2020). Prevention efforts with compliance to the prevention of transmission of COVID-19 to COVID volunteers. Journal of Public Health Research and Community Health Development, 4(1), 81. https://doi.org/10.20473/jphrecode.v4i1.21792

Asemahagn, M. A. (2020). Factors determining the knowledge and prevention practice of healthcare workers towards COVID-19 in Amhara region, Ethiopia: a cross-sectional survey. Tropical Medicine and Health, 48(1), 72. https://doi.org/10.1186/s41182-020-002543

Ashcroft, R., Donnelly, C., Dancey, M., Gill, S., Lam, S., Kourgiantakis, T., Adamson, K., Verrilli, D., Dolovich, L., Kirvan, A., Mehta, K., Sur, D., \& Brown, J. B. (2021). Primary care teams' 
experiences of delivering mental health care during the COVID - 19 pandemic : a qualitative study. BMC Family Practice, 1-12. https://doi. org/10.1186/s12875-021-01496-8

Cai, Z., Cui, Q., Liu, Z., Li, J., Gong, X., Liu, J., Wan, Z., Yuan, X., Li, X., Chen, C., \& Wang, G. (2020). Nurses endured high risks of psychological problems under the epidemic of COVID-19 in a longitudinal study in Wuhan China. Journal of Psychiatric Research, 131(April), 132-137. https://doi.org/10.1016/j. jpsychires.2020.09.007

Cooper, S., Wiyeh, A., Schmidt, B. M., \& Wiysonge, C. S. (2020). Cochrane corner: Factors that influence compliance by healthcare workers with infection prevention and control guidelines for COVID-19 and other respiratory infections. Pan African Medical Journal, 35(2), 1-3. https:// doi.org/10.11604/pamj.2020.35.2.23012

Fang, X., Zhang, J., Teng, C., Zhao, K., Su, K. P., Wang, Z., Tang, W., \& Zhang, C. (2020). Depressive symptoms in the frontline nonmedical workers during the COVID-19 outbreak in Wuhan. Journal of Affective Disorders, 276(July), 441-445. https://doi.org/10.1016/j. jad.2020.06.078

Haque, A., Mumtaz, S., Mumtaz, R., Masood, F., Buksh, H. A., Ahmed, A., \& Khattak, O. (2021). Assessment of knowledge, perceptions and perceived risk concerning COVID-19 in Pakistan. Journal of Epidemiology and Global Health, 11(2), 186-193. https://doi.org/http:// dx.doi.org/10.2991/jegh.k.210109.001

Jemal, S., Zeleke, M., Tezera, S., Hailu, S., Abdosh, A., Biya, M., \& Abduljelil, S. (2019). Health care workers' knowledge, attitude and practice towards infection prevention in Dubti referral hospital, Dubti, North East Ethiopia. International Journal of Advanced Community Medicine, 2(1), 30-36. https://doi. org/10.33545/comed.2019.v2.i1a.07

Maude, R. R., Jongdeepaisal, M., Skuntaniyom, S., Muntajit, T., Blacksell, S. D., Khuenpetch, W., Pan-Ngum, W., Taleangkaphan, K., Malathum, K., \& Maude, R. J. (2021). Improving knowledge, attitudes and practice to prevent COVID-19 transmission in healthcare workers and the public in Thailand. BMC Public Health, 21(1), 1-14. https://doi.org/10.1186/s12889021-10768-y

Mikola, D., Wright, T., Beland, L., Brodeur, A., \& Mikola, D. (2020). The Short-Term Economic Consequences of COVID-19: Occupation Tasks and Mental Health in Abel Brodeur. Disscussion Paper Series Institute of Labor Economics. Retrieved January 14, 2021, from http://ftp.iza.org/dp13254.pdf

Ministry of Health Republic of Indonesia. (2020, September). Current Situation Developments (COVID-19). In Ministry of Health Republic of Indonesia (17-19). Retrieved January 21, 2021, from https://covid19.kemkes.go.id/
download/Situasi Terkini 050520.pdf

Moudy, J., \& Syakurah, R. A. (2020). Pengetahuan terkait usaha pencegahan Coronavirus Disease (COVID-19) di Indonesia. Higeia Journal of Public Health Research and Development, 4(3), 333-346. https://doi. org/10.15294/higeia.v4i3.37844

Nuccetelli, M., Pieri, M., Grelli, S., Ciotti, M., Miano, R., Andreoni, M., \& Bernardini, S. (2020). SARS-CoV-2 infection serology: A useful tool to overcome lockdown?. Cell Death Discovery, 6(1). https://doi.org/10.1038/s41420-0200275-2

Olum, R., Chekwech, G., Wekha, G., Nassozi, D. R., \& Bongomin, F. (2020). Coronavirus Disease-2019: Knowledge, attitude, and practices of health care workers at Makerere University Teaching Hospitals, Uganda. In Frontiers in Public Health, 8. https://doi. org/10.3389/fpubh.2020.00181

Qian, X., Ren, R., Wang, Y., Guo, Y., Fang, J., Wu, Z. D., Liu, P. L., \& Han, T. R. (2020). Fighting against the common enemy of COVID-19: A practice of building a community with a shared future for mankind. Infectious Diseases of Poverty, 9(1), 4-9. https://doi.org/10.1186/ s40249-020-00650-1

Rahman, M. A., Hoque, N., Alif, S. M., Salehin, M., Islam, S. M. S., Banik, B., Sharif, A., Nazim, N. B., Sultana, F., \& Cross, W. (2020). Factors associated with psychological distress, fear and coping strategies during the COVID-19 pandemic in Australia. Globalization and Health, 16(1), 1-15. https://doi.org/10.1186/ s12992-020-00624-w

Saqlain, M., Munir, M. M., Rehman, S. U., Gulzar, A., Naz, S., Ahmed, Z., Tahir, A. H., \& Mashhood, M. (2020). Knowledge, attitude, practice and perceived barriers among healthcare workers regarding COVID-19: A cross-sectional survey from Pakistan. Journal of Hospital Infection, 105(3), 419-423. https://doi.org/10.1016/j. jhin.2020.05.007

Shen, F., Chen, M., Lu, Y., \& Chu, Y. (2021). The effect of cognition and affect on preventive behaviors during the COVID-19 pandemic: a cross-sectional study in China. BMC Public Health, 21, 1-8. https://doi.org/http://dx.doi. org/10.1186/s12889-021-10784-y

Singh, D. R., Sunuwar, D. R., Shah, S. K., Karki, K., Sah, L. K., Adhikari, B., \& Sah, R. K. (2021). Impact of COVID-19 on health services utilization in Province-2 of Nepal: A qualitative study among community members and stakeholders. BMC Health Services Research, 21(1), 1-14. https://doi.org/10.1186/s12913021-06176-y

Sugawara, E., \& Nikaido, H. (2014). Properties of AdeABC and AdelJK efflux systems of Acinetobacter baumannii compared with those of the AcrAB-TolC system of Escherichia coli. Antimicrobial Agents and Chemotherapy, 
58(12), 7250-7257. https://doi.org/10.1128/ AAC.03728-14

Tamang, N., Rai, P., Dhungana, S., Sherchan, B., Shah, B., Pyakurel, P., \& Rai, S. (2020). COVID-19: a National Survey on perceived level of knowledge, attitude and practice among frontline healthcare Workers in Nepal. BMC Public Health, 20(1), 1-10. https://doi. org/10.1186/s12889-020-10025-8

The Central Bureau of Statistics Malang. (2020). The number of health workers in districts in Malang 2018-2019. Retrieved July 14, 2021 from https://malangkota.bps.go.id/ indicator/30/358/1/jumlah-tenaga-kesehatanmenurut-kecamatan.html

Tsegaye, D., Shuremu, M., Oljira, D., Dubale, S., Befekadu, G., \& Bidira, K. (2021). COVID - 19 related knowledge and preventive practices early in the outbreak among health care workers in selected public health facilities of Illu aba Bor and Buno Bedelle zones, Southwest Ethiopia. BMC Infectious Diseases, 21(1), 490. https://doi.org/10.1186/s12879-021-06218-0

Viswanathan, R., Myers, M. F., \& Fanous, A. H. (2020). Support Groups and Individual Mental Health Care via Video Conferencing for Frontline Clinicians During the COVID-19 Pandemic. Psychosomatics, 1-6. https://doi. org/10.1016/j.psym.2020.06.014

WHO. (2020). WHO Coronavirus Disease (COVID-19) Dashboard Data last updated: 2020/8/21, 10:25am CEST. https://covid19. who.int/

World Health Organization. (2020). Material COVID-19 Risk Communication for Health Care Facilities (pp. 1-15). https://www.who.int/ docs/default-source/searo/indonesia/covid19/ risk-communication-for-healthcare-facility. pdf?sfvrsn=9207787a_2
Wright, J. K., Tan, D. H. S., Walmsley, S. L., Hulme, J., O'Connor, E., Snider, C., Cheng, I., Chan, A. K., Borgundvaag, B., McLeod, S., Gollob, M. H., Clarke, R. J., Dresser, L., Haji, F., Mazzulli, T., Mubareka, S., Jüni, P., Lee, D., Tomlinson, G., ... Landes, M. (2020). Protecting frontline health care workers from COVID-19 with Hydroxychloroquine pre-exposure prophylaxis: A structured summary of a study protocol for a randomised placebo-controlled multisite trial in Toronto, Canada. Trials, 21(1), 20-22. https:// doi.org/10.1186/s13063-020-04577-8

Yanti, B., Wahyudi, E., Wahiduddin, W., Novika, R. G. H., Arina, Y. M. D., Martani, N. S., \& Nawan, N. (2020). Community knowledge, attitudes, and behavior towards social distancing policy as prevention transmission of COVID-19 in Indonesia. Jurnal Administrasi Kesehatan Indonesia, 8(2), 4. https://doi.org/10.20473/ jaki.v8i2.2020.4-14

Yifan, T., Ying, L., Chunhong, G., Jing, S., Rong, W., \& Zhenyu, L. (2020). Symptom cluster of ICU nurses treating COVID-19 pneumonia patients in Wuhan, China. Journal of Pain and Symptom Management, 60(1), e48-e53. https://doi. org/10.1016/j.jpainsymman.2020.03.039

Yue, S., Zhang, J., Cao, M., \& Chen, B. (2021). Knowledge, attitudes and practices of COVID-19 among urban and rural residents in China: A Cross-sectional Study. Journal of Community Health, 46(2), 286-291. https:// doi.org/10.1007/s10900-020-00877-x

Zhang, M., Zhou, M., Tang, F., Wang, Y., Nie, H., Zhang, L., \& You, G. (2020). Knowledge, attitude, and practice regarding COVID-19 among healthcare workers in Henan, China. Journal of Hospital Infection, 105(2), 183-187. https://doi.org/10.1016/j.jhin.2020.04.012 